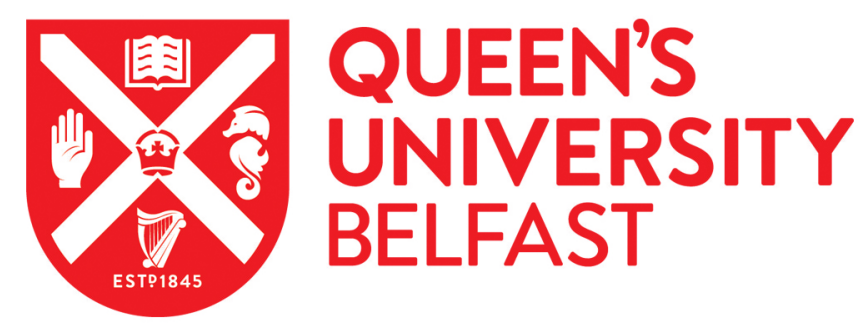

\title{
Time and Cell Type Dependency of Survival Responses in Co- cultured Tumor and Fibroblast Cells after Exposure to Modulated Radiation Fields
}

Butterworth, K. T., McMahon, S. J., McKee, J. C., Patel, G., Ghita, M., Cole, A. J., McGarry, C. K., O'Sullivan, J. M., Hounsell, A. R., \& Prise, K. M. (2015). Time and Cell Type Dependency of Survival Responses in Cocultured Tumor and Fibroblast Cells after Exposure to Modulated Radiation Fields. Radiation Research, 183(6), 656-664. https://doi.org/10.1667/RR13992.1

\section{Published in:}

Radiation Research

Document Version:

Publisher's PDF, also known as Version of record

Queen's University Belfast - Research Portal:

Link to publication record in Queen's University Belfast Research Portal

Publisher rights

(c) 2015 Radiation Research Society.

\section{General rights}

Copyright for the publications made accessible via the Queen's University Belfast Research Portal is retained by the author(s) and / or other copyright owners and it is a condition of accessing these publications that users recognise and abide by the legal requirements associated with these rights.

Take down policy

The Research Portal is Queen's institutional repository that provides access to Queen's research output. Every effort has been made to ensure that content in the Research Portal does not infringe any person's rights, or applicable UK laws. If you discover content in the Research Portal that you believe breaches copyright or violates any law, please contact openaccess@qub.ac.uk. 


\title{
Time and Cell Type Dependency of Survival Responses in Co-cultured Tumor and Fibroblast Cells after Exposure to Modulated Radiation Fields
}

\author{
Karl T. Butterworth, ${ }^{a, 1}$ Stephen J. McMahon, ${ }^{a, d}$ Jamie C. McKee,${ }^{a}$ Gaurang Patel, ${ }^{a}$ Mihaela Ghita ${ }^{a}$ Aidan J. Cole ${ }^{a, b}$ \\ Conor K. McGarry, ${ }^{c}$ Joe M. O’Sullivan, ${ }^{a, b}$ Alan R. Hounsell ${ }^{c}$ and Kevin M. Prise ${ }^{a}$ \\ ${ }^{a}$ Centre for Cancer Research and Cell Biology, Queen's University Belfast, Belfast, Northern Ireland, United Kingdom; ${ }^{b}$ Clinical Oncology and \\ 'Radiotherapy Physics, Northern Ireland Cancer Centre, Belfast, Northern Ireland, United Kingdom; and ' Department of Radiation Oncology, \\ Massachusetts General Hospital and Harvard Medical School, Boston, Massachusetts
}

Butterworth, K. T., McMahon, S. J., McKee, J. C., Patel, G., Ghita, M., Cole, A. J., McGarry, C. K., O'Sullivan, J. M., Hounsell, A. R. and Prise, K. M. Time and Cell Type Dependency of Survival Responses in Co-cultured Tumor and Fibroblast Cells after Exposure to Modulated Radiation Fields. Radiat. Res. 183, 656-664 (2015).

Advanced radiotherapy techniques such as intensitymodulated radiation therapy (IMRT) achieve high levels of conformity to the target volume through the sequential delivery of highly spatially and temporally modulated radiation fields, which have been shown to impact radiobiological response. This study aimed to characterize the time and cell type dependency of survival responses to modulated fields using single cell type (SCT) and mixed cell type (MCT) co-culture models of transformed fibroblast (AG0-1522b) cells, prostate (DU-145) and lung (H460) cancer cells. In SCT cultures, in-field responses showed no significant time dependency while out-of-field responses occurred early, and plateaued $6 \mathrm{~h}$ after irradiation in both DU-145 and H460 cells. Under modulated beam configurations MCT cocultures showed cell-specific, differential out-of-field responses depending on the irradiated in-field and responding out-offield cell type. The observed differential out-of-field responses may be due to the genetic background of the cells, in particular p53 status, which has been shown to mediate radiation-induced bystander effects (RIBEs). These data provide further insight into the radiobiological parameters that influence out-of-field responses, which have potential implications for advanced radiotherapy modalities and may provide opportunities for biophysical optimization in radiotherapy treatment planning. @ 2015 by Radiation Research Society

\section{INTRODUCTION}

Modern radiotherapy approaches are able to deliver a high uniform dose across the tumor target volume while sparing

1 Address for correspondence: Centre for Cancer Research and Cell Biology, Queen's University Belfast, 97 Lisburn Road, Belfast, BT9 7BL; e-mail: k.butterworth@qub.ac.uk. surrounding healthy tissue. This is achieved using multiple overlapping radiation fields with high levels of spatial and temporal modulation during a typical treatment plan delivery. While advanced radiotherapy techniques such as intensity-modulated radiotherapy (IMRT) efficiently conform dose to the tumor target, areas outside of the primary treatment fields may be exposed to a nontrivial dose, which accumulates due to contributing dose from multiple beams, scattered photons, transmission and leakage photons during treatments. The radiobiological implications of out-of-field dose for late occurring sequelae, risk of secondary cancers and therapeutic response have yet to be determined.

A current series of in vitro studies, reported by our laboratory and others [reviewed in ref. (1)], have shown significant alterations in cell survival after exposure to modulated fields, which is dependent not only on the dose delivered to the target, but also on that delivered to neighboring cell populations (2-4). The effects occurring out-of-field are partially driven by intercellular communication and display similarities to classical radiation-induced bystander effects (RIBEs) (5). Additionally, out-of-field effects may be influenced by variations in incident beam energy spectra $(6,7)$. Also, theoretical analyses have shown that radiation-induced signaling may have significant effects not only in regions out-of-field exposed to a low dose, but also in high-dose regions within the tumor target volume $(8-10)$. These effects were recently analyzed in prostate radiotherapy treatment planning, showing contributions of signaling effects both in tumor and normal tissues, with similar effects seen for a range of treatment modalities (11). Existing experimental studies focusing on out-of-field responses in vitro have been conducted using cultures of a single cell type $(2,3,12,13)$. In contrast, tumor biology in vivo is a significantly more complex environment that includes not only tumor cells but also various different normal cell types. Similarly, at tumor margins, communication between irradiated malignant cells and normal healthy tissue is likely to have an important role in the overall response of both tissues. 
In the current study, the time and cell type dependency of survival responses were characterized after exposure to modulated radiation fields in single and mixed cell type cocultures. The purpose of this approach was to more accurately model the cell signaling between tumor and normal tissues that occurs at tumor margins or within the tumor microenvironment in vivo.

\section{MATERIALS AND METHODS}

\section{Cell Cultures}

Cell lines were selected to include tumor and fibroblast cells from different sites with varying radiosensitivities. Human prostate cancer cells (DU-145) and non-small cell lung cancer cells (H460) were obtained from LGC Standards, Ltd. (Bury, UK) and maintained in RPMI-1640 media with 10\% fetal bovine serum (FBS) and 1\% penicillin/streptomycin (Sigma-Aldrich Company Ltd., Dorset, UK). Human primary fibroblast cells (AG0-1522b) were obtained from the Coriell Institute for Medical Research (Camden, NJ), and were grown in Eagle's minimum essential media (deoxyribonucleosides and deoxyribonucleotides) with $20 \%$ FBS and $100 \mu \mathrm{g} / \mathrm{ml}$ streptomycin. All cells were maintained at $37^{\circ} \mathrm{C}$ in a humidified atmosphere of $95 \%$ air $/ 5 \% \mathrm{CO}_{2}$.

\section{Clonogenic Assay}

Cell survival was determined by the clonogenic assay technique of Puck and Marcus (14). Generally, cells were detached from culture flasks by incubating in a $1: 1$ solution of $0.25 \%$ trypsin and $1 \mathrm{mM}$ EDTA, centrifuged and resuspended in fresh culture media. Cells were counted using a Coulter counter set at a threshold calibrated for the cell line using a hemocytometer and plated at an appropriate optimum cell density to ensure colony formation for survival analysis. Once plated the cells were allowed to adhere overnight before irradiation at room temperature $\left(20-23^{\circ} \mathrm{C}\right)$. After irradiation cell cultures were incubated for $10-14$ days at $37^{\circ} \mathrm{C}$ in $5 \% \mathrm{CO}_{2}$ in air and $95 \%$ humidity before staining with crystal violet. Colonies exceeding 50 cells were scored as representing surviving cells. All exposures were performed in duplicate on at least three independent occasions. On each occasion unexposed control cells were prepared and treated as sham exposures, which included unirradiated control used at each time point for the temporal studies.

\section{Cell Co-culture}

Co-culture studies were performed by seeding cells on glass slides using the protocol described above and allowing cells to adhere overnight. Slides were then transferred to $150 \mathrm{~cm}^{2}$ culture flasks with reclosable lids (TPP Techno Plastic Products AG, Trasadingen, Switzerland) and irradiated in shared media. For single cell type exposures, all cells were irradiated in the media specified above. For mixed cell type co-culture, all cells were irradiated in AG0-1522b culture media and maintained for $6 \mathrm{~h}$, which has been shown to have no effect on the plating efficiency. Cells were then reseeded in their respective culture media and appropriate seeding densities.

\section{Irradiation Set-up and Experimental Design}

All cells were irradiated with $225 \mathrm{kVp} X$ rays using an X-Rad 225 generator (Precision X-ray Inc., North Bradford, CT) with a $2 \mathrm{~mm}$ copper filter at a dose rate of $0.57 \mathrm{~Gy} \mathrm{~min}^{-1}$ and a field diameter of 22 $\mathrm{cm}$. A modulated beam was created by shielding $50 \%$ of the culture flask using low melting point alloy (MCP96; Mining and Chemical Products Ltd., Northants, UK). Dosimetry measurements for the modulated beam were performed using a Farmer ionization chamber at an in-field distance of $2 \mathrm{~cm}$ to ensure delivery of the correct absolute dose. Calibrated Gafchromic ${ }^{\mathrm{TM}}$ EBT film (International Specialty Products, Wayne, NJ) was exposed and used to generate a dose profile along the central axis, coincident with the plane of cells. Dose delivered to the out-of-field region was taken as the dose $2 \mathrm{~cm}$ from the central axis, and was determined using a Farmer ${ }^{\circledR}$ ionization chamber $(15,16)$. A schematic representation of the experimental setup and dose profile is shown in Fig. 1.

\section{Data Analysis}

For each of the irradiation conditions, surviving fractions (SF) were calculated as the ratio of the number of colonies in the exposed flask to the number of seeded cells, corrected for the plating efficiency of sham-irradiated controls. Uniform field survival curves were fitted to the form, $S F=\exp \left[-\left(\alpha D+\beta D^{2}\right)\right]$, using OriginPro, version 8 (OriginLab ${ }^{\circledR}$ Inc., Northampton, MA). Statistical errors on fit values were calculated as the standard error. All experiments were performed in triplicate with the data presented as \pm standard error in all cases. Statistical analysis comparing the survival values for uniform and modulated beam exposures incubated under same cell type and mixed cell type co-culture conditions was carried out using an unpaired $t$ test (GraphPad Prism, version 5.01; GraphPad Software Inc., LaJolla, CA), with a threshold for significance at the level of $P<0.05$.

\section{RESULTS}

Cell survival was determined after exposure to uniform and modulated fields in same cell type cultures or mixed cell type co-cultures containing tumor (DU-145 or H460) and fibroblast cells (AG0-1522b). Radiation dose-response curves for each of the cell lines exposed to a uniform beam configuration are shown in Fig. 2A-C. Radiosensitivity parameters were determined by fitting to the linearquadratic model as follows: DU-145 $(\alpha=0.13 \pm 0.03$, $\beta=0.02 \pm 0.01) ; \mathrm{H} 460(\alpha=0.16 \pm 0.02, \beta=0.03 \pm$ $0.01)$; and AG0-1522b $(\alpha=0.38 \pm 0.01, \beta=0 \pm 0.01)$.

\section{Temporal Dependency of Radiation-Induced Signaling Effects for Modulated Beam Exposures}

The temporal dependency of radiation-induced signaling effects between in- and out-of-field regions was determined by irradiation of single cell type cultures (SCT) with a modulated field followed by replating at time intervals up to $24 \mathrm{~h}$ after irradiation. For DU-145 cells at a dose of $8 \mathrm{~Gy}$, in-field survival responses showed no time dependency, remaining constant at around $10-15 \%$ at time intervals up to $24 \mathrm{~h}$ (Fig. 3A). This observation was consistent in H460 irradiated with the same dose, which showed no significant change $(P>0.05)$ for in-field response up to $24 \mathrm{~h}$ postirradiation (Fig. 4A). In both cases, in-field responses were comparable to those observed for uniform exposures at around $10 \%$ and $3 \%$ in DU-145 and H460 cells, respectively.

In contrast, out-of-field survival responses showed a significant temporal component of response with similar trends observed in both cell lines, with survival reaching a minimum level of $60-70 \%$ at $6 \mathrm{~h}$ postirradiation. At $24 \mathrm{~h}$ postirradiation, a $10 \%$ increase in survival was observed in H460 cells but not DU-145 cells. These data indicated that 

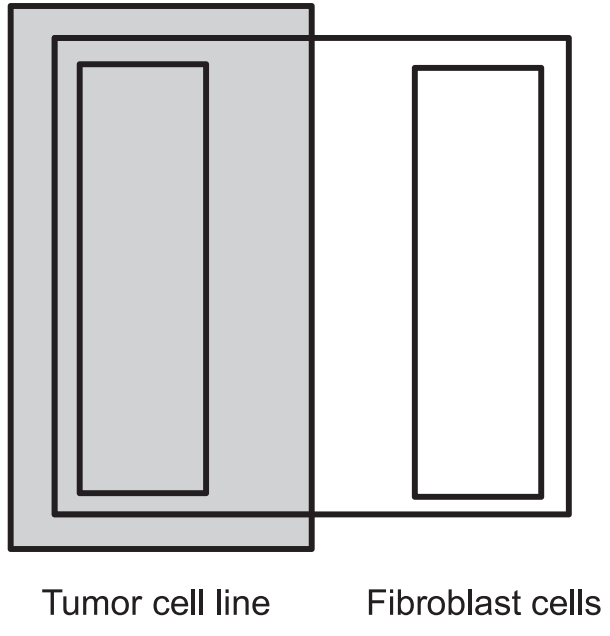

(DU-145 or H460)

(AG0-1522b)
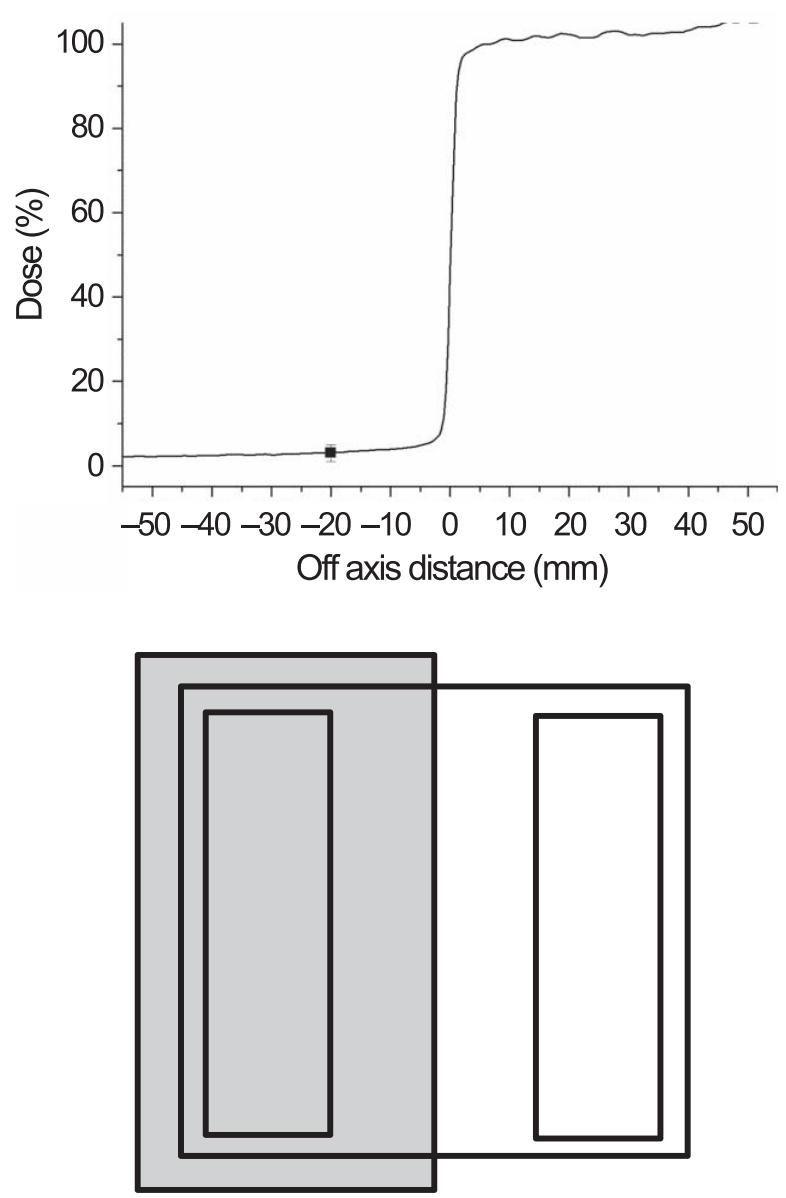

Fibroblast cells Tumor cell line

(AG0-1522b)

(DU-145 or H460)

FIG. 1. Schematic representation of the irradiation setup for mixed cell cultures and dose profile for modulated radiation field exposures. Cells were cultured on microscope slides and transferred to culture flasks with reclosable lids for co-culture conditions. Cells were irradiated with the center of the flask aligned with shielding edge. Dose profiles were measured using Gafchromic film at various distances off axis and a single ionization chamber measurement 20 $\mathrm{mm}$ off axis out-of-field.
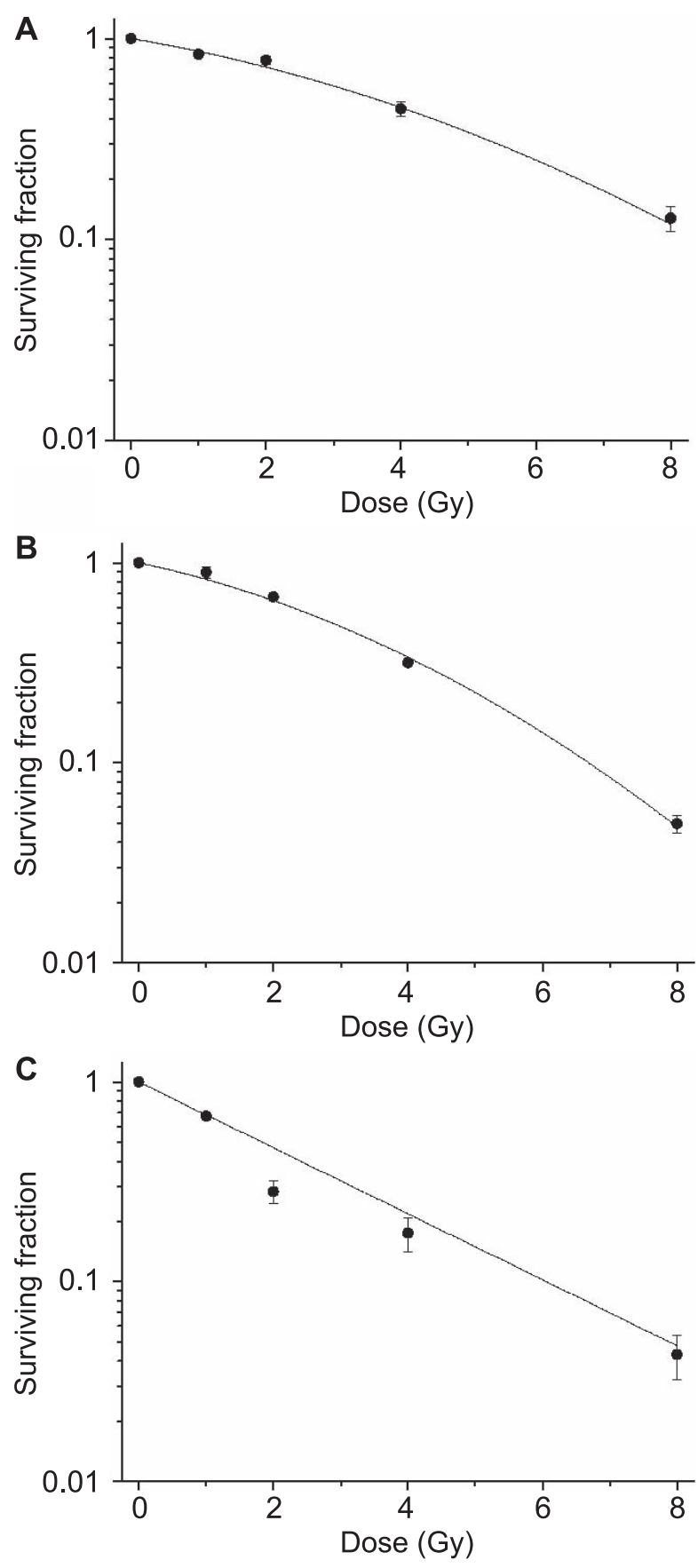

FIG. 2. Radiation dose-response curves for DU-145 (panel A), H460 (panel B) and AG0-1522b (panel C) and cells after exposure to uniform radiation fields. Survival curves were fitted to the LQ model. Error bars indicate \pm standard error of the mean.

the majority of radiation-induced signaling between the infield and out-of-field regions occurs within $6 \mathrm{~h}$ after irradiation. All subsequent experiments were therefore conducted by replating cells $6 \mathrm{~h}$ after irradiation. These data were fitted according to a previously published model of bystander signaling (8), with an additional term to reflect cell doubling before replating (with a mean doubling time of $24 \mathrm{~h}$ ). 

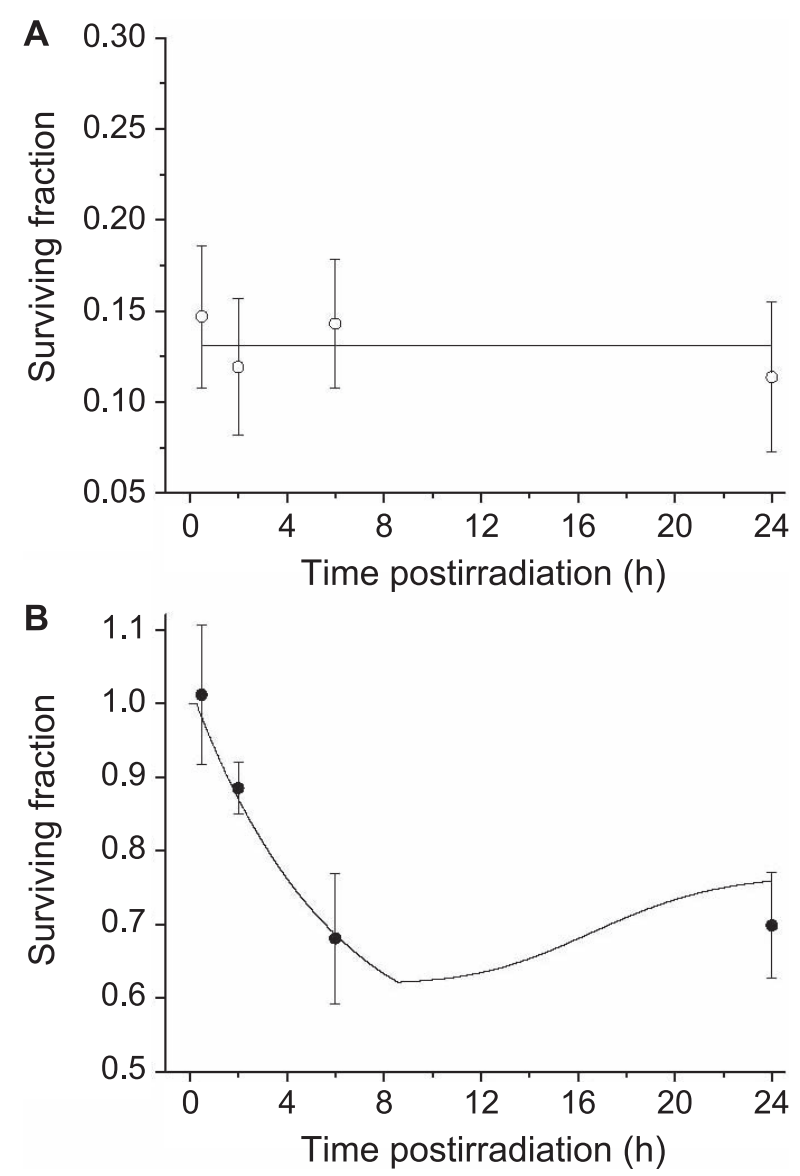

FIG. 3. Temporal dependency of the in-field (panel A) and out-offield (panel B) survival responses for DU-145 cells after exposure to a modulated radiation field. In-field responses (panel A) were shown to be constant across the time intervals investigated and out-of-field responses (panel B) were fitted using the kinetic-based model of bystander signaling of McMahon et al. (8).

\section{Dose and Cell Type Dependency of Survival Responses}

To characterize cell-specific signaling between the tumor and normal cells under modulated beam conditions, experiments were performed by irradiating single cell type cultures or DU-145, H460, AG0-1522b or mixed cell type (MCT) co-cultures of tumor (DU-145 or H460 cells) with fibroblast (AG0-1522b) cells.

Survival responses of DU-145 cells in SCT and MCT coculture conditions were determined at in-field doses of 4 and 8 Gy (Fig. 5A, B). Under SCT culture conditions, DU145 cells showed no significant difference in uniform field response compared to in-field responses to modulated beam exposures at doses of 4 and 8 Gy $(P>0.05)$. Out-of-field responses, where the dose was around 3\% of that delivered in field, showed no dose dependency with survival at $80 \%$ with doses at 4 and 8 Gy.

Co-culturing DU-145 cells with AG0-1522b was shown to impact survival response. At $4 \mathrm{~Gy}$, no significant difference in uniform field response was observed between SCT and MCT co-culture $(P>0.05)$. However, in-field survival was significantly lower than that observed for
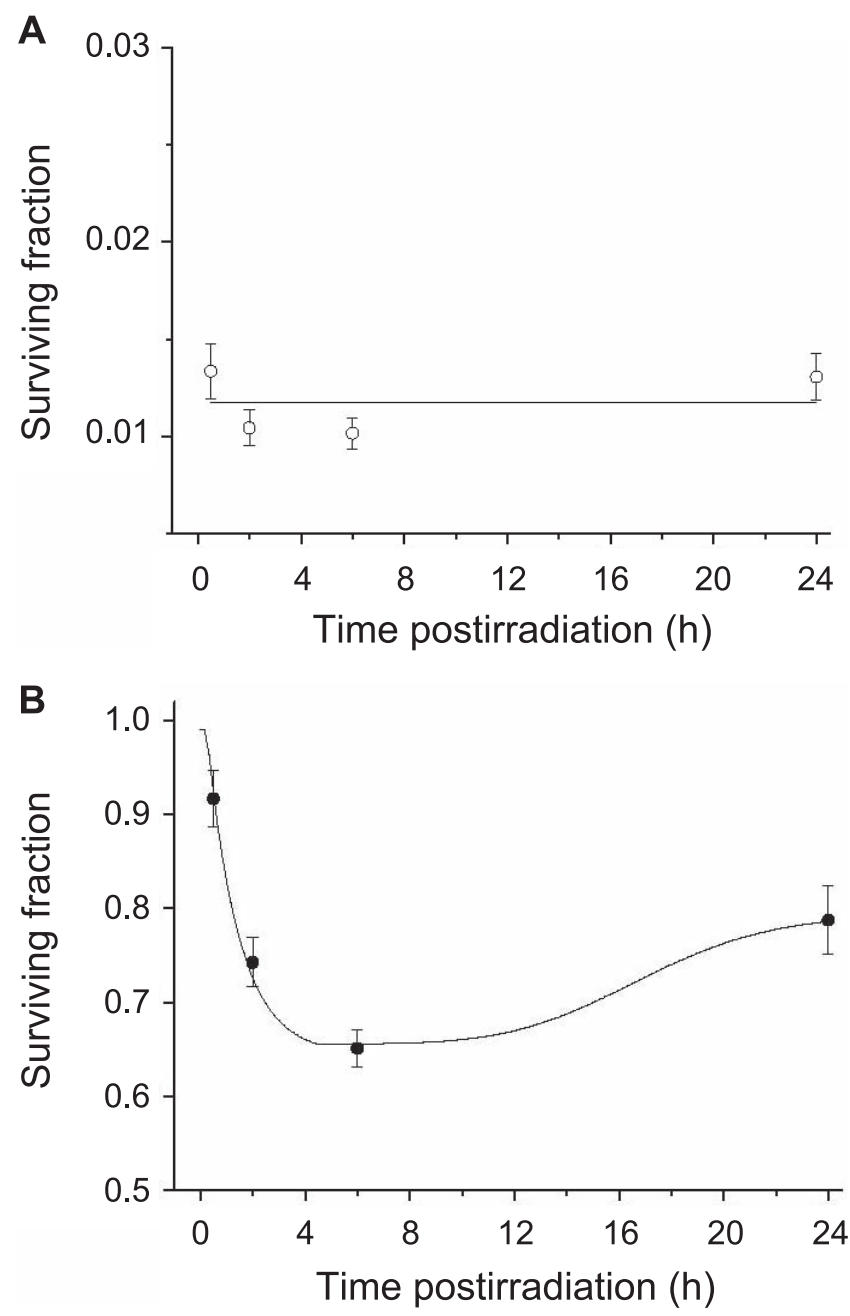

FIG. 4. Temporal dependency of the in-field (panel A) and out-offield (panel B) survival responses for $\mathrm{H} 460$ cells after exposure to a modulated radiation field. In-field responses (panel A) were shown to be constant across the time intervals investigated and out-of-field responses (panel B) were fitted using the kinetic-based model of bystander signaling of McMahon et al. (8).

uniform exposures in MCT co-cultures $(P=0.02)$, as well as both uniform and in-field response in SCT conditions $(P<0.002)$. At $8 \mathrm{~Gy}$, uniform and in-field responses were not significantly different $(P>0.05)$ under MCT co-culture conditions. However, both were significantly lower than those observed for SCT conditions $(P<0.002)$. Out-offield responses were consistent with those observed under SCT conditions at around $80 \%$ survival for in-field doses at 4 and $8 \mathrm{~Gy}$.

The same experimental procedures were performed with H460 cells as SCT or MCT co-cultures with AG0-522b cells at doses of 4 (Fig. 6A) and 8 Gy (Fig. 6B). When irradiated as SCT cultures, H460 cells showed no significant difference $(P>0.05)$ in uniform field response compared to in-field responses for modulated beam exposures at doses of 4 and 8 Gy. Out-of-field responses displayed no dose dependency with around 90\% survival at in-field doses of 4 and $8 \mathrm{~Gy}$. 


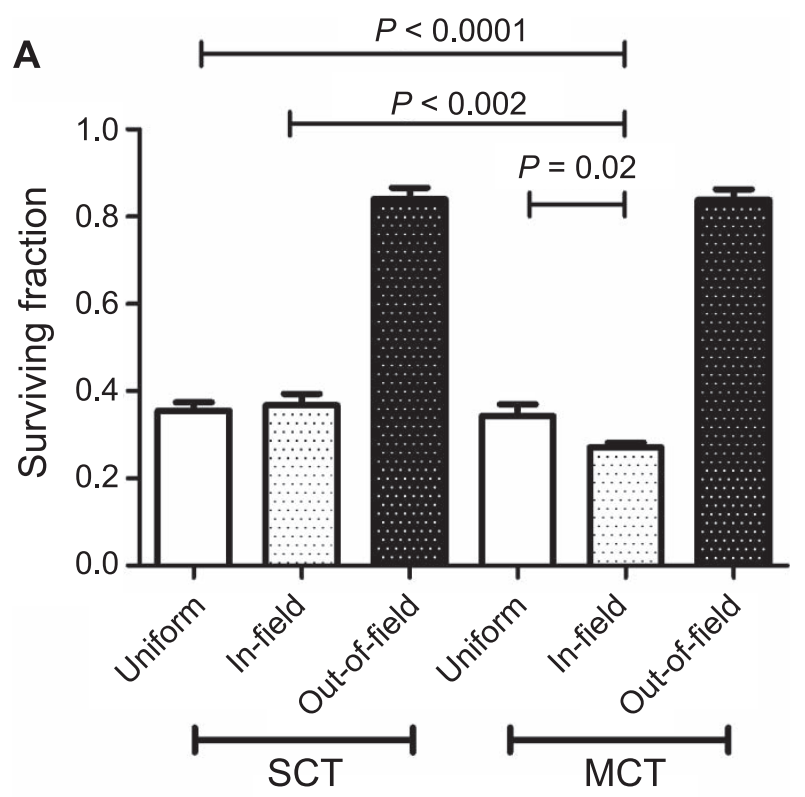

Exposure and incubation conditions

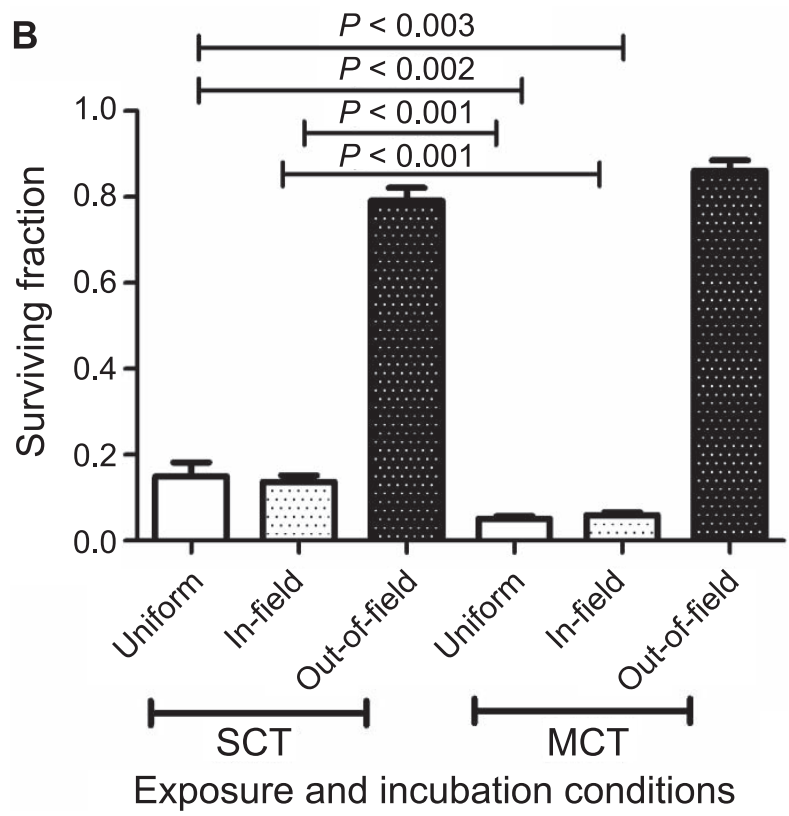

FIG. 5. Comparison of survival responses for DU-145 cells exposed to uniform and modulated fields as single cell type (SCT) or mixed cell type (MCT) cultures at 4 Gy (panel A) and 8 Gy (panel B) doses. MCT cultures were performed by co-culturing with AG0-1522b cells.

For MCT conditions at $4 \mathrm{~Gy}$, no significant difference was observed in uniform field responses compared to SCT conditions $(P>0.05)$. The in-field survival was significantly higher than that observed for uniform exposures under the same exposure conditions $(P=0.02)$ and in-field under SCT conditions $(P<0.001)$. A similar trend was observed at $8 \mathrm{~Gy}$, where the in-field survival was shown to be significantly higher than for uniform fields $(P<0.001)$ and both the uniform and in-field survival under SCT conditions $(P<0.001)$. Out-of-field survival was signifi-
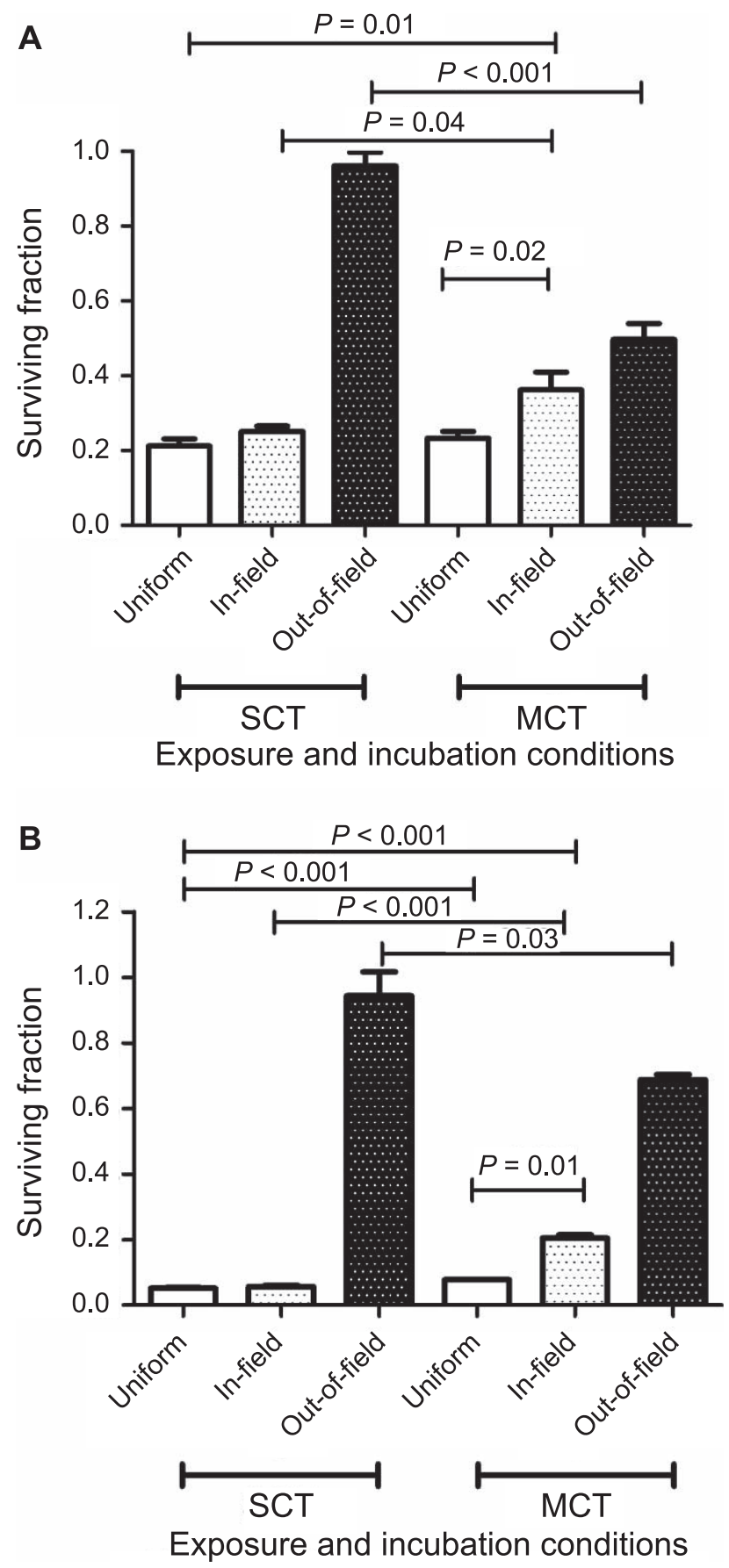

FIG. 6. Comparison of survival responses for $\mathrm{H} 460$ cells exposed to uniform and modulated beam configurations as single cell type (SCT) or mixed cell type (MCT) cultures at 4 Gy (panel A) and 8 Gy (panel B) doses. MCT cultures were performed by co-culturing with AG0-1522b cells.

cantly lower compared to that observed under SCT conditions, falling to around $50-60 \%$ at in-field doses of 4 and 8 Gy $(P<0.01)$.

AG0-1522b cells were irradiated at a single dose of 4 Gy as SCT and MCT co-cultures with DU-145 (Fig. 7A) and H460 cells (Fig. 7B). When irradiated as SCT cultures, uniform and in-field responses were consistent at $10 \%$ in- 


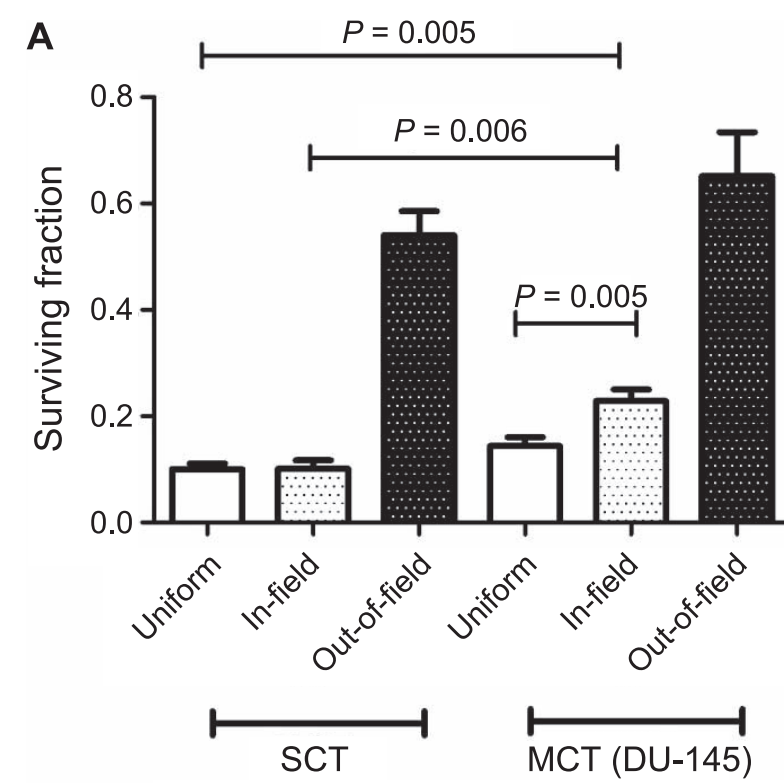

Exposure and incubation conditions

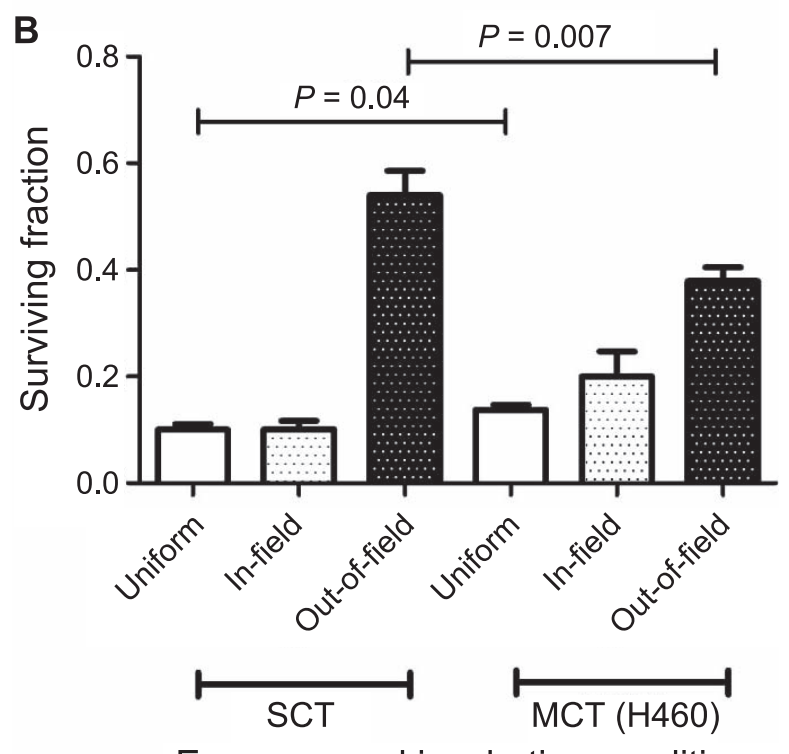

Exposure and incubation conditions

FIG. 7. Comparison of survival responses for AG0-1522b cells exposed to uniform and modulated beam configurations as single cell type (SCT) or mixed cell type (MCT) cultures at a 4 Gy (panel B) dose. MCT cultures were performed by co-culturing AG0-1522b cells with DU-145 (panel A) or H460 (panel B) cells.

field survival with around $50 \%$ occurring out-of-field. When co-cultured with DU-145 cells, in-field survival was significantly higher than that observed for SCT conditions $(P=0.006)$ and for uniform exposures under both SCT $(P=$ $0.005)$ and MCT $(P=0.005)$ conditions. Out-of-field survival increased to greater than $60 \%$ but was not shown to be significant when compared with that for SCT exposures $(P>0.05)$. Co-culturing with $\mathrm{H} 460$ cells showed a trend towards increased in-field survival, however the only significant difference in survival was shown between uniform exposures $(P=0.04)$. Out-of-field survival decreased to less than $40 \%(P=0.007)$.

\section{DISCUSSION}

Advanced intensity-modulated radiotherapy techniques commonly used in clinical practice have significantly different spatial and temporal dose delivery characteristics compared to conventional, uniform radiation exposures (17). A number of investigators have attempted to further understand the radiobiology underpinning the responses to spatially modulated radiation fields [reviewed in ref. (l)] by using different experimental set-ups and end points, and have shown significant differences in cell survival occurring outside of the primary radiation field. These differences cannot be accounted for on the basis of scattered dose and may be driven by radiation-induced bystander effects (RIBEs) between regions in and out of the primary field and the low-energy component of incident beam spectra.

While RIBEs have classically been demonstrated at the cellular level in vitro using techniques including media transfer and co-culture, exposure to modulated radiation fields is a useful experimental approach to investigate RIBEs under conditions that more accurately represent clinical exposures (18). To date, investigations in this area have used single cell culture models, which fail to accurately represent cell-signaling effects between tumor and normal cells that may be occurring at margins or distinct compartments within the tumor microenvironment.

In the current study, a cell co-culture system was utilized to assess the kinetics of response between tumor and fibroblast cells and to characterize cell-specific effects on radiobiological responses after exposure to intensity-modulated fields. Initial experiments determined the radiosensitivity of DU-145, H460 and AG0-1522b cells to $225 \mathrm{kVp}$ $\mathrm{X}$ rays. To allow co-culture responses to be investigated under modulated field conditions, the kinetics of cellular signaling between in- and out-of-field regions was determined. Both DU-145 and H460 cells showed similar kinetics of response up to $24 \mathrm{~h}$ after exposure. In-field responses showed no temporal dependency without significant changes in survival response up to $24 \mathrm{~h}$ in both DU145 and H460 cells (Figs. 2A and 3A). In contrast, out-offield responses were shown to be strongly dependent on incubation time, sharing media with the in-field population. Both cell lines showed a similar response with out-of-field survival falling to a minimum level of around $70 \%$ and $65 \%$ in DU-145 and H460 cells, respectively, $6 \mathrm{~h}$ after irradiation. Trends towards increased survival at $24 \mathrm{~h}$ were seen, although this was significant only in H460 cells. This is attributed to repopulation of cells within the out-of-field regions. These data are in close agreement with our previously reported model of cell signaling under these beam configurations ( 8 ) and suggest that the production, transduction and response to signals from in-field irradiated 
cells is an early event occurring less than $6 \mathrm{~h}$ after irradiation.

Several reports have demonstrated a time component to bystander signaling using both media transfer and coculture techniques, which are in agreement with our data under modulated beam conditions. Mothersill et al. (19) observed a time dependency of response when media were transferred from donor populations of $\mathrm{HaCaT}$ and SW48 cells irradiated with doses of 5 Gy and 2 Gy, respectively, with the most significant effects occurring within $3 \mathrm{~h}$ of irradiation. Using a co-culture model, Yang et al. (20) showed significant time dependency of bystander responses at the DNA damage level when nonirradiated cells were cocultured with irradiated cells $6 \mathrm{~h}$ or later after irradiation with $1 \mathrm{GeV}$ ions and $250 \mathrm{kVp} \mathrm{X}$ rays.

In addition, Han et al. (21) provided evidence supporting even earlier induction and initiation of RIBEs in AG0$1522 \mathrm{~b}$ cells. This was of the order of $2.5 \mathrm{~min}$ by media transfer and $30 \mathrm{~min}$ for partial cell population irradiations with low-dose alpha particles. These studies support our current experimental data suggesting that the generation of signaling mediated RIBEs occurs relatively early after irradiation, within $6 \mathrm{~h}$ in DU-145 cells, and provided the rationale for conducting co-culture studies at this time after irradiation.

In single type co-cultures, survival data for uniform and modulated beam responses are consistent with previous reports from our laboratory $(3,22)$ with the exception of the out-of-field responses for DU-145 and H460 cells. At a dose of 4 Gy using $6 \mathrm{MV}$ photons, Cole et al. (19) reported outof-field responses of around 65 and $75 \%$ in $\mathrm{H} 460$ and DU145 cells, respectively. For $225 \mathrm{kVp} \mathrm{X}$ rays at the same dose, Trainer et al. (3) observed an out-of-field response of around $70 \%$ in DU-145 cells. At 4 Gy, these values compare to around $80 \%$ in DU-145 and $90 \%$ in $\mathrm{H} 460$ cells. These differences may be attributed to different experimental set-ups, most significantly the continuous culturing of cells after irradiation for the duration of the assay. However, these differences could be further validated by investigating the temporal dependency of out-of-field responses at time points longer than $24 \mathrm{~h}$ after irradiation. Moving to more complex models of radiation-induced signaling between tumor and fibroblast cells in mixed cell type co-cultures, the data are more difficult to generalize. Cell-specific effects are observed depending on the in-field and out-of-field cell types.

Similar effects have previously been reported in the literature, again using both media transfer and co-culture techniques. In the same report detailing time dependency, Mothersill et al. (19) also showed cell specificity where media from irradiated epithelial cells generated a RIBE when transferred to fibroblast cells, but not when media from fibroblasts were transferred to epithelial cells. Similarly, Ryan et al. (23) investigated RIBEs by media transfer in six human cell lines and observed cell-specific effects relating to radiosensitivity and p53 status of the irradiated cell type.

More recently, evidence of differential RIBEs was demonstrated using co-cultures of chondrosarcoma and fibroblast exposed to different qualities of radiation, specifically X rays, protons, iron and carbon ions (24). The study showed chondrosarcoma cells to be capable of generating a bystander signal while remaining unresponsive to bystander signals from irradiated fibroblasts.

The impact of beam energy and radiation quality on RIBEs remains contradictory. Although not the subject of this investigation, an important study by Anzenberg et al. (25) compared the effects of $250 \mathrm{kVp} \mathrm{X}$ rays and $\alpha$ particles in various co-culture configurations of DU-145 and AG01522b. At the cell survival level, nonirradiated AG0-1522b cells showed a significant decrease when co-cultured for $4 \mathrm{~h}$ with X-irradiated DU-145 cells. In the opposing configuration, nonirradiated DU-145 cells exposed to irradiated AG0-1522b cells showed no decrease in surviving fraction. These data partially agree with our findings, which show: 1 . AG0-1522b cells are responsive to radiation-induced signaling from DU-145 cells but to a lower extent than those from AG0-1522b cells in-field (Fig. 7A); and 2. DU145 cells are equally responsive to signaling from in-field AG0-1522b and DU-145 cells.

Genetic background, particularly p53 status, has been shown to have an important role in mediating RIBEs in vitro and in vivo (26-29). The cell models used in this study are of different p53 backgrounds, specifically, DU-145 (p53 mutant), AG0-1522b (p53 wild-type) and $\mathrm{H} 460$ (p53 wildtype) (30-32), which we postulate is likely to affect out-offield response. Using different combinations of media transfer from p53 wild-type and p53 null HTC116 cells, Mothersill et al. (28) showed that both p53 wild-type and p53 null cells are capable of producing signals that induce RIBEs, but that only p53 wild-type cells can respond to signals produced from either cell type. Furthermore, He et al. (33) showed that RIBEs can be modulated by the p53 status of irradiated hepatoma cells and that a p53-dependent release of cytochrome-c may be involved in mediating response.

At the organism level, abscopal effects have been shown to be p53 dependent. Using C57BL/6 (wild-type p53) and p53 null B6.129S2-Trp53tm1Tyj mice, Camphausen et al. (29) observed significant growth delay effects in Lewis lung carcinoma (LLC) and T241 (fibrosarcoma) implanted at a distant site after irradiation of the nontumor leg only when p53 was intact. In addition, Strigari et al. (27) further demonstrated a role for p53 status in abscopal effects using xenograft tumor models of p53 wild-type and p53 null HTC166 cells and showed significant growth delay effects in contralateral only when p53 was intact.

Although co-culturing of different monolayer cell types is an incremental improvement beyond single cell type cultures, it does not accurately represent the clinical scenario where complex interactions between multiple cell 
types of different genetic backgrounds may occur during exposure to spatially and temporally modulated fields. Accurate recapitulation of these conditions to determine the role of RIBEs in vivo under complex beam configurations requires the application of more sophisticated experimental approaches that may be experimentally possible with small animal image-guided radiotherapy systems $(34,35)$.

In conclusion, to our knowledge this is the first reported study to characterize the time dependency and cell specificity of out-of-field effects to modulated beam exposures, which share similar characteristics with RIBEs observed by media transfer and X-ray microbeam techniques (36). These effects are likely to be driven by similar molecular mechanisms, including p53 status, and may be important in the refinement of existing dose-based radiobiological models in optimizing radiotherapy treatment planning.

\section{ACKNOWLEDGMENTS}

The authors wish to acknowledge financial support from CRUK (C1513/A707 and C212/A11342) and Prostate Cancer UK (S10-08).

Received: December 12, 2014; accepted: March 12, 2015; published online: May 14, 2015

\section{REFERENCES}

1. Asur R, Butterworth KT, Penagaricano JA, Prise KM, Griffin RJ. High dose bystander effects in spatially fractionated radiation therapy. Cancer Lett 2013; 356:52-7.

2. Butterworth KT, McGarry CK, Trainor C, O'Sullivan JM, Hounsell AR, Prise KM. Out-of-field cell survival following exposure to intensity-modulated radiation fields. Int J Radiat Oncol 2011; 79:1516-22.

3. Trainor C, Butterworth KT, McGarry CK, Liberante F, Sullivan JMO, Hounsell AR, et al. Cell survival responses after exposure to modulated radiation fields. Radiat Res 2012; 51:44-51.

4. Butterworth KT, McGarry CK, Trainor C, McMahon SJ, O'Sullivan JM, Schettino G, et al. Dose, dose-rate and field size effects on cell survival following exposure to non-uniform radiation fields. Phys Med Biol 2012; 57:3197-206.

5. Prise KM, O'Sullivan JM. Radiation-induced bystander signalling in cancer therapy. Nat Rev Cancer 2009; 9:351-60.

6. Shields L, Vega-Carrascal I, Singleton S, Lyng FM, McClean B. Cell survival and DNA damage in normal prostate cells irradiated out-of-field. Radiat Res 2014; 182:499-506.

7. Syme A, Kirkby C, Mirzayans R, MacKenzie M, Field C, Fallone BG. Relative biological damage and electron fluence in and out of a 6 MV photon field. Phys Med Biol 2009; 54:6623-33.

8. McMahon SJ, Butterworth KT, Trainor C, McGarry CK, O'Sullivan JM, Schettino G, et al. A kinetic-based model of radiation-induced intercellular signalling. PLoS One 2013; 8:e54526.

9. McMahon SJ, Butterworth KT, McGarry CK, Trainor C, O'Sullivan JM, Hounsell AR, et al. A computational model of cellular response to modulated radiation fields. Int J Radiat Oncol Biol Phys 2012; 84:250-6.

10. Ebert MA, Suchowerska N, Jackson MA, McKenzie DR. A mathematical framework for separating the direct and bystander components of cellular radiation response. Acta Oncol 2010; 49:1334-43.

11. McMahon SJ, McGarry CK, Butterworth KT, O'Sullivan JM, Hounsell AR, Prise KM. Implications of intercellular signaling for radiation therapy: a theoretical dose-planning study. Int $\mathrm{J}$ Radiat Oncol Biol Phys 2013; 87:1148-54.

12. Suchowerska N, Ebert MA, Zhang M, Jackson M. In vitro response of tumour cells to non-uniform irradiation. Phys Med Biol 2005; 50:3041-51.

13. Mackonis EC, Suchowerska N, Zhang M, Ebert M, McKenzie DR, Jackson M. Cellular response to modulated radiation fields. Phys Med Biol 2007; 52:5469-82.

14. Puck T, Marcus P. Action of x-rays on mammalian cells. J Exp Med 1956; 103:653-66.

15. Aukett RJ, Burns JE, Greener AG, Harrison RM, Moretti C, Nahum AE, et al. Addendum to the IPEMB code of practice for the determination of absorbed dose for $\mathrm{x}$-rays below $300 \mathrm{kV}$ generating potential $(0.035 \mathrm{~mm} \mathrm{Al}-4 \mathrm{~mm} \mathrm{Cu} \mathrm{HVL})$. Phys Med Biol 2005; 50:2739-48.

16. The IPEMB code of practice for the determination of absorbed dose for x-rays below $300 \mathrm{kV}$ generating potential $(0.035 \mathrm{~mm} \mathrm{Al}-4$ $\mathrm{mm} \mathrm{Cu} \mathrm{HVL}$; 10-300 kV generating potential). Institution of Physics and Engineering in Medicine and Biology. Phys Med Biol 1996; 41:2605-25.

17. McGarry CK, Butterworth KT, Trainor C, O'Sullivan JM, Prise $\mathrm{KM}$, Hounsell AR. Temporal characterization and in vitro comparison of cell survival following the delivery of 3Dconformal, intensity-modulated radiation therapy (IMRT) and volumetric modulated arc therapy (VMAT). Phys Med Biol 2011; 56:2445-57.

18. Butterworth KT, McMahon SJ, Hounsell AR, O'Sullivan JM, Prise KM. Bystander signalling: exploring clinical relevance through new approaches and new models. Clin Oncol (R Coll Radiol) 2013; 25:586-92.

19. Mothersill C, Seymour C. Medium from irradiated human epithelial cells but not human fibroblasts reduces the clonogenic survival of unirradiated cells. Int J Radiat Biol 1997; 71:421-7.

20. Yang H, Anzenberg V, Held KD, Skin H, Radiat F. The time dependence of bystander responses induced by iron-ion radiation in normal human skin fibroblasts. Radiat Res 2007; 298:292-8.

21. Han W, Wu L, Hu B, Zhang L, Chen S, Bao L, et al. The early and initiation processes of radiation-induced bystander effects involved in the induction of DNA double strand breaks in non-irradiated cultures. Br J Radiol 2007; 80 Spec No 1:S7-12.

22. Cole AJ, McGarry CK, Butterworth KT, McMahon SJ, Hounsell $\mathrm{AR}$, Prise $\mathrm{KM}$, et al. Investigating the influence of respiratory motion on the radiation induced bystander effect in modulated radiotherapy. Phys Med Biol 2013; 58:8311-22.

23. Ryan LA, Smith RW, Seymour CB, Mothersill CE. Dilution of irradiated cell conditioned medium and the bystander effect. Radiat Res 2008; 169:188-96.

24. Wakatsuki M, Magpayo N, Kawamura H, Held KD. Differential bystander signaling between radioresistant chondrosarcoma cells and fibroblasts after $\mathrm{x}$-ray, proton, iron ion and carbon ion exposures. Int J Radiat Oncol Biol Phys 2012; 84:e103-8.

25. Anzenberg V, Chandiramani S, Coderre JA. LET-dependent bystander effects caused by irradiation of human prostate carcinoma cells with x rays or alpha particles. Radiat Res 2008; 476:467-76.

26. Irons SL, Serra V, Bowler D, Chapman K, Militi S, Lyng F, et al. The effect of genetic background and dose on non-targeted effects of radiation. Int J Radiat Biol 2012; 88:735-42.

27. Strigari L, Mancuso M, Ubertini V, Soriani A, Giardullo P, Benassi M, et al. Abscopal effect of radiation therapy: interplay between radiation dose and p53 status. Int J Radiat Biol 2014; 90:248-55.

28. Mothersill C, Bristow RG, Harding SM, Smith RW, Mersov A, Seymour CB. A role for p53 in the response of bystander cells to receipt of medium borne signals from irradiated cells. Int J Radiat Biol 2011; 87:1120-5.

29. Camphausen K, Moses MA, Me C, Sproull M, Beecken W, 
Folkman J, et al. Radiation abscopal antitumor effect is mediated through p53. Cancer Res 2003; 63:1990-3.

30. Bajgelman MC, Strauss BE. The DU-145 human prostate carcinoma cell line harbors a temperature-sensitive allele of p53. Prostate 2006; 66:1455-62.

31. Ghosh SP, Perkins MW, Hieber K, Kulkarni S, Kao T, Reddy EP, et al. Radiation protection by a new chemical entity, Ex-Rad: efficacy and mechanisms. Radiat Res 2009; 171:173-9.

32. Sun Y, Myers CJ, Dicker AP, Lu B. A novel radiation-induced p53 mutation is not implicated in radiation resistance via a dominantnegative effect. PLoS One 2014; 9:e87492.

33. He M, Zhao M, Shen B, Prise KM, Shao C. Europe PMC Funders
Group Radiation-induced intercellular signaling mediated by cytochrome-c via a p53-dependent pathway in hepatoma cells. Oncogene 2011; 30:1947-55.

34. Verhaegen F, Granton P, Tryggestad E. Small animal radiotherapy research platforms. Phys Med Biol 2011; 56:R55-83.

35. Butterworth KT, Prise KM, Verhaegen F. Small animal imageguided radiotherapy: status, considerations and potential for translational impact. Br J Radiol 2015; 88:20140634.

36. Prise KM, Schettino G, Vojnovic B, Belyakov O, Shao C. Microbeam studies of the bystander response. J Radiat Res 2009; 50 Suppl:A1-6. 